\title{
Surfaces
}

\section{LEGITIMIZING ELECTRONIC SCHOLARLY PUBLICATIONS: A DISCURSIVE PROPOSAL}

\section{Rod Heimpel}

Volume 8, 1999

HUMANITÉS ET INFORMATIQUE : QUI A LES COMMANDES ?

HUMANITIES AND COMPUTING: WHO'S DRIVING?

URI : https://id.erudit.org/iderudit/1065076ar

DOI : https://doi.org/10.7202/1065076ar

Aller au sommaire du numéro

Éditeur(s)

Les Presses de l’Université de Montréal

ISSN

1188-2492 (imprimé)

1200-5320 (numérique)

Découvrir la revue

Citer cet article

Heimpel, R. (1999). LEGITIMIZING ELECTRONIC SCHOLARLY PUBLICATIONS: A DISCURSIVE PROPOSAL. Surfaces, 8. https://doi.org/10.7202/1065076ar
Résumé de l'article

La publication électronique de recherches universitaires n'est pas une publication en papier sous de nouveaux atours. Pour légitimer les publications universitaires électroniques, il importe de proposer une nouvelle compréhension des fondements institutionnels du monde de l'universitaire. Malgré le fait que les pages Web ne sont que des copies de documents auxquelles un usager demande accès, l'utilisation de la souris dans la sélection des documents implique un espace. La communauté est une métaphore logique pour décrire cet espace. Insister sur l'idée de communautés virtuelles spécialisées comporte des enjeux pour l'institution universitaire dans son ensemble.
Copyright (C) Rod Heimpel, 1999

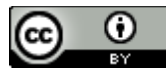

Ce document est protégé par la loi sur le droit d'auteur. L'utilisation des services d'Érudit (y compris la reproduction) est assujettie à sa politique d'utilisation que vous pouvez consulter en ligne.

https://apropos.erudit.org/fr/usagers/politique-dutilisation/ 


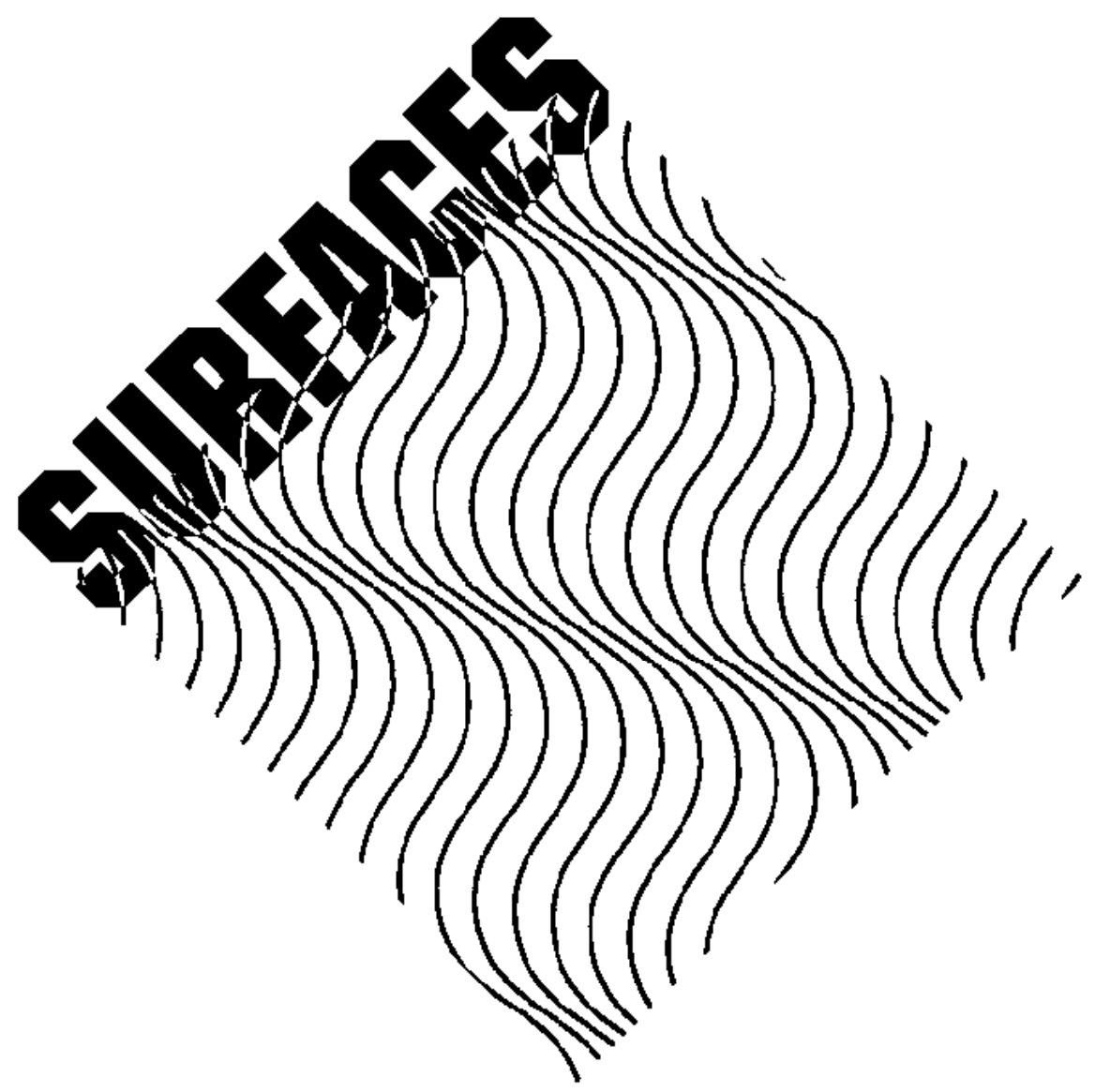

LEGITIMIZING ELECTRONIC SCHOLARLY PUBLICATIONS : A DISCURSIVE PROPOSAL

$\underline{\text { Rod Heimpel }}$ 


\section{Rédacteur en chef:}

Jean-Claude Guédon

\section{Comité fondateur:}

Wlad Godzich

Walter Moser

Michel Pierssens
Christie McDonald

Antonio Gómez-Moriana

Gilles Bibeau

\section{Remerciements:}

SURFACES peut paraître grâce à un soutien des Presses de l'Université de Montréal, ainsi qu'à une aide matérielle importante (locaux, mobilier, services informatiques) de l'Université de Montréal.

\section{Adresses:}

\section{SURFACES}

Département de littérature comparée Université de Montréal C.P. 6128, succ. Centre-ville Montréal, Qc, Canada H3C 3J7

Tél.: (514) 3435683

Fax: (514) 3435684

Accès sur INTERNET www.pum.umontreal.ca/revues/surfaces

Assistance technique et questions éditoriales: guedon@ere.umontreal.ca

ISSN: $1188-2492$ 


\section{Soumission des textes}

Vous pouvez soumettre vos articles, revues, notes, commentaires ou autres aux éditeurs par courrier électronique, par disquette ou par lettre. En ce qui concerne les notes bibliographiques, veuillez suivre le protocole du MLA. Nous vous demandons également de joindre à votre texte un court résumé de 3 à 4 lignes.

Tout article publié que l'auteur voudra modifier ultérieurement sera de nouveau évalué. Si accepté, il se substituera à la première version avec une nouvelle date et la mention v. 2.

Tout texte reste la propriété de son auteur. Néanmoins, SURFACES demande d'être citée à l'occasion de toute autre publication du texte en question.

\section{Citation des textes}

Pour toute citation, veuillez consulter le document source afin d'obtenir la dernière version du texte qui vous intéresse et vous baser sur la pagination flottante (/pp. xx/) plutôt que sur la foliation (pied de page). Si vous n'avez pas accès au courrier électronique, adressez-vous aux éditeurs qui pourront vous vendre une copie papier ou sur disquette. 


\title{
RÉSUMÉ
}

La publication électronique de recherches universitaires n'est pas une publication en papier sous de nouveaux atours. Pour légitimer les publications universitaires électroniques, il importe de proposer une nouvelle compréhension des fondements institutionnels du monde de l'universitaire. Malgré le fait que les pages Web ne sont que des copies de documents auxquelles un usager demande accès, l'utilisation de la souris dans la sélection des documents implique un espace. La communauté est une métaphore logique pour décrire cet espace. Insister sur l'idée de communautés virtuelles spécialisées comporte des enjeux pour l'institution universitaire dans son ensemble.

\begin{abstract}
An electronic publication of scholarly work is not merely a paper publication in disguise. Legitimizing electronic scholarly publications calls for a new understanding of institutional underpinnings of the scholar's world. Despite the fact that webpages are merely copies requested manually, by clicking on a mouse, they are conceived in spatial terms. Community is a logical metaphor for this space. Insistance on the idea of specialized virtual communities involves questions for the whole of the university institution.
\end{abstract}


A writer dies and goes to Heaven. Writer's Heaven. Being a writer, he is quite naturally curious about Heaven and Hell. So upon meeting Saint Peter at the pearly gates, he asks if it would be possible to visit Hell briefly before ascending to Heaven. Saint Peter, obliging as ever, is happy to grant the writer's request. In a flash, they arrive in writer's Hell where they feast their eyes upon thousands of writers planted in front of thousands of typewriters, arranged in rows as far as the eye could see, a damp, dark, foul place, full of the overpowering stench of decomposition and putrefaction. "Just as I expected," says the writer to Saint Peter. "I'm ready to see Heaven now." In a flash, they arrive in writer's Heaven where they feast their eyes upon thousands of writers planted in front of thousands of typewriters, arranged in rows as far as the eye could see, a damp, dark, foul place, full of the overpowering stench of decomposition and putrefaction. "But this is the same as Hell," the writer objects. "Not at all," says Saint Peter. "Their work is published."

\section{1) Introduction}

Despite the recent flourish of controversy, the debate surrounding the integration of computer technology in academic publishing is not new. In fact, a few pioneering university librarians were already investigating the "electronic option" in the 1970's, at a time when computing technology was bulky, performance challenged, extremely expensive and user unfriendly. ${ }^{1}$ /pp. 5-6/

1 See Ann Okerson, "Back to Academia: The Case for American Universites to Publish Their Own Research," Yale University, Nov. 29, 1998 <http://www.library.yale.edu/ okerson/case.html>. See also Charles W. Bailey Jr., "Network-Based Electronic Publishing of Scholarly Works: A Selective Bibliography," The Public-Access Computer Systems Review 6.1 (1995): 5-21. Also available online: "Scholarly Electronic Publishing Bibliography" University of Houston Libraries, 29 Nov. 1998 <http://info.lib.uh.edu/sepb/sepb.html>. 
Support from scholars engaged in the nascent field of humanities computing was very limited; and as with the introduction of most new technologies, suspicion was widespread. As a result, many of the sound ideas and ambitious visions of this period were never implemented. Retrospectively, however, this has in one sense turned out to be a blessing in disguise, given the fact that applications written during this period are now at the heart of the Year 2000 problem (Y2K).

Today, computers and computer networking are extremely technologically advanced and relatively inexpensive, the cost of memory and storage media is plummeting, and thanks to the popularity of the World Wide Web, academics finally have access to powerful, affordable authoring tools. Furthermore, computing has also evolved socially: the electronic environments of the 1990's have been built on and have flourished due in large part to the set of "democratic" attitudes, shared responsibilities and collaborative efforts made possible by a user-oriented approach to computing. Think of the public domain Apache server, international organizations like the World Wide Web Consortium, the LINUX movement and the trend towards voluntary compliance.

Meanwhile, in the papyrocentric ${ }^{2}$ world of traditional scholarly publishing, the evidence of crisis has been mounting steadily, much to the horror of researchers, librarians and students. For example:

/pp. 6-7/

2 I have borrowed this term from Steven Harnad (Princeton University). See "Scholarly Journals at the Crossroads: A Subversive Proposal for Electronic Publishing: An Internet Discussion about Scientific and Scholarly Journals and Their Future," eds. Ann Shumelda Okerson and James J. O'Donnell, April 9, 1998, Association of Research Libraries, Washington, DC, 29 Nov. 1998 <http://www.arl.org/scomm/subversive/sub01.html>. 
Statistics from the Association of Research Libraries show that from 1986 to 1993, the unit price of serials more than doubled (an increase of 108 per cent), while the cost of monographs increased by nearly half (46 per cent). Although expenditures on serials and monographs increased by 92 and 16 per cent respectively, the number of serials and monographs purchased declined (a drop of 5 per cent and 23 per cent). ${ }^{3}$

Librarians have been speaking of crisis for some time now, and administrators and scholars are slowly adopting a similar rhetoric of disaster. One issue that emerges in librarian accounts of the state of scholarly publication is the complacency, even the negligence of scholars with respect to maintaining control over their own intellectual output:

About $70 \%$ of scientific journal articles carry university addresses, but universities are increasingly unable to "buy back" their own work. It is not surprising that a vision of university-based publishing captures the imagination of parts of academe. A marketing survey in 1990 determined that universities publish at most $15 \%$ of their scholars' output. It is a stretchy $15 \%$, including not only work of university presses, but also publications of individual academic

3 See "The Changing World of Scholarly Communication: Challenges and Choices for Canada. Final report of the AUCC-CARL/ABRC Task Force on Academic Libraries and Scholarly Communication," Nov. 1996, Association of Universities and Colleges of Canada and the Canadian Association of Research Libraries, N ov. 29, 1998

<http://homer.aucc.ca/english/sites/aucccarl.htm>. "Publishing scholarly journals is certainly a profitable business. According to Forbes magazine, London-based Reed Elsevier, the largest publisher of academic journals, probably earned US\$225 million before taxes on 1994 revenues of US\$600 million from its academic publishing operations. Further complicating this cost picture, since the great majority of academic commercial publishers are located outside this country, are the ups and downs of international currency exchange" ("Knowledge Dissemination"). 
departments, working papers and periodicals. /pp. 7-8/ About $90 \%$ of formal academic publications migrate outside the academy before returning home as repurchased monographs and serials. There are no hard data about what proportion of that $90 \%$ is produced by scholarly and scientific societies as opposed to the commercial sector, but soft evidence suggests that since World War Il half or more of what used to be not-for-profit output is now commercially published. Universities could compete and influence price by retrieving control of a proportion of the academic literature and strengthen the arm of university publishing, withered through lack of interest, support, glamour or profitability. (Okerson "Back to Academia")

Yet it would be hypocritical to lay the blame for the crisis squarely on the shoulders of profiteering commercial publishers. University faculties and departments have enlisted similar attitudes and practices by accepting more and more students into graduate programs who will be expected to publish sooner and more in their careers, in order to pine after fewer and fewer attractive tenure-track positions. Alas:

Not every branch of "publishing" is equally healthy in the late twentieth century. The romance novel is robustly successful, but the scientific journal and the scholarly monograph are threatened by rising costs, rising output, and constrained academic budgets. The most painful paradox is that in the interests of science, the law of the market cannot be allowed to function. (Okerson \& O'Donnell, Introduction, editors' emphasis)

While scientific journals are often more costly than their humanities counterparts, and scientific results may be more time-sensitive, the above conclusion still applies with equal force to the humanities. /pp. 8-9/ 
Despite the impressive projects of a growing list of scholars and a plethora of conferences and position papers 4 , as well as informal online discussions, electronic scholarly publication has not had the impact in this time of crisis that one might have expected. In the humanities, most young and senior academics prefer to publish on paper, to publish books if possible; many academics in senior administrative positions do not accept electronic publications as legitimate; students have expressed resistance to the online publication of their doctoral theses 5 . There are many new and wonderful online publications 6 , but most well-known journals have not migrated to the web, despite its clear financial and communicative advantages. And what is even more surprising is that librarians, administrators and scholars are generally in agreement as to the origin of this sluggish implementation process: the slow move toward electronic scholarly publication is predominantly a social question, and is no longer, for the most part, a technological problem. /pp. 9-10/

4 For a useful summary of this activity, see "The Electronic Library and the Future of Scholarly Communication," a.c.u. bulletin of current documentation (Association of Commonwealth Universities): 131 (Dec. 1997): 10-16.

5 See DesJardins, Joseph. "Status of ETD Initiatives in the US and Canada." Sept. 1997. Joint Electronic Thesis and Dissertation Project of the Faculty of Information Studies at the University of Toronto, University of Toronto Libraries and York University Libraries. 29 Nov. 1998 <http://www.fis.utoronto.ca/etd/report1.htm>. In particular, see "Student Opposition" <http://www.fis.utoronto.ca/etd/report1.htm\#univ>: "Objections included in a rather long list were: lack of control over their own property, the sense of being human test subjects, future preservation of their thesis, draconian contractual agreements. The bottom line for many was simply that publishers such as the American Psychological Association, American Chemical Society and University of Chicago, for example, do not consider web-published material for p-publication".

6 For example, see "New Jour: Electronic Journals and Newsletters," eds. Ann Shumelda Okerson and James J. O'Donnell, Nov. 29, 1998, University of California at San Diego Libraries, Nov. 29, 1998 <http://gort.ucsd.edu/newjour/>. At last count, there were 6764 electronic publications on this list.

S U R F A C E S Vol. VIII.104 
The question therefore becomes: How can the specificity of scholarly electronic publications (e-publications) be stressed without inviting claims of inferiority vis-à-vis paper publications (p-publications)? The response I am proposing in this article treats resistance to e-publication as an essentially ideological or conceptual problematic. Examples are drawn from both scientific and humanities scholarly publication, since the conceptual problematic analysed and the solution proposed apply to both fields. Section 2 examines how different approaches to the integration of new technologies inevitably make certain assumptions about the nature of change, its "felicity conditions," 7 and limits. In Section 3, "Metaphor as Strategy," the claims of similarity between p-publications and e-publications made by incrementalist integration approaches are analysed as a kind of metaphorical argument. Section 4 describes the extreme strain and pressure exerted on the publication metaphor by the recent barrage of new printing and publishing technologies. In the final section, "Beyond the Publication Principle," I argue for an alternative metaphorisation of scholarly e-publications as virtual communities. In other words, the legitimization of scholarly e-publication must be approached as a discursive or rhetorical issue: we do not need to change what we are doing, but rather how it is framed as a value that can be protected.

\section{2) Approaching Change}

Fine efforts have been made to overcome institutional resistance to electronic publication. These approaches to change can be roughly classified as either hard break or as incrementalist approaches. Professor Stevan Harnad's "subversive proposal" (1994) is certainly the most noteworthy example of the /pp. 10-11/

7 I have borrowed this term from John L. Austin, How to do Things With Words (Oxford: Oxford University Press, 1962). In How to do Things with Words, Austin proposes this term to describe the conditions which must be fulfilled to bring about a successful speech act. Since change is often effected via speech acts and other discursive strategies, the analogy is, I think, quite felicitous. 
hard break approach. His proposal is subversive in several ways. It is linguistically subversive in its description of academic publishing as "esoteric publication": publication that targets the limited audiences of scholarly and scientific publications. (This esoteric usage of the term esoteric earned him his fair share of criticism.) Most important, it is institutionally subversive: "[if] every esoteric author in the world this very day established a globally accessible local ftp archive for every piece of esoteric writing from this day forward, the long-heralded transition from paper publication to purely electronic publication (of esoteric research) would follow suit immediately" (Okerson \& O'Donnell, Overture). Despite some success with this "storm the Bastille" approach (e.g. Paul Ginsparg's HEP, see Okerson \& O'Donnell), its appeal tends to be more emotional than practical or practicable. This is particularly true in the humanities where research is not, for the most part, time-sensitive.

Other less subversive, but no less thoughtful approaches have erred on the side of caution. For the purposes of discussion, I will refer to these approaches as incrementalist. These approaches have focused on aligning the infrastructure of e-publications with those of p-publications. This practice can be summarized, grosso modo, as follows:

1) Academic infrastructure: electronic publications are (or can be) refereed with the same degree of rigour as their paper counterparts. Here the intellectual standards are safeguarded against the ease and openness of the electronic frontier.

2) Publication infrastructure: electronic publications will be maintained at the same online address and will provide alternative sites in some cases, called "mirror sites," capable of rerouting traffic in the event of web congestion or server downtime. Furthermore, the more copies of a document that exist in various forms, the greater the odds that copies will survive for future generations. Here, by analogy, the enduring and reliable quality of paper publications is reconstituted in the electronic medium. /pp. 11-12/ 
3) Document standards: e-publications adopt the standards of p-publications, including the consistent use of copyright notices, ISO characters, ISSN and pages numbers and attractive layouts. Here, by analogy, documents made available via an online environment will very closely resemble their paper counterparts.

The approach that Rob Kling and Lisa Covi refer to as polymorphous constitutes an important incrementalist model, combining the efficiency of e-publication with the institutional legitimacy of p-publication. Citing the example of the Journal of Artificial Intelligence Research, Kling and Covi explain that:

Its editors cleverly exploit the broad rapid international distribution afforded by Internet services such as WWW, while simultaneously calming authors' fears of publishing in a stigmatized electronic medium because it always looks like a p-journal and can be purchased in paper form. In fact, JAIR's editors encourage readers to cite articles published in JAIR in the same format that they would cite a p-journal article (and they do not encourage citations to include URLs). [...] Its authors and readers are part of a scholarly community where there is strong consensus on a computerized typesetting format (in this case Postscript), and in which every research lab has free (or subsidized) electronic access to Internet services. And JAIR is allied with a (commercial) publisher that routinely markets and sells books to libraries, scholars and professionals. One other key feature of JAIR's stealth approach is that it doesn't broadcast its e-journal status in its name. It is a fascinating model. (Kling \& Covi)

All of this leads the authors to the conclude that "JAIR leaves no traces of its e-journal status for academic administrators such as department chairs and deans to sneer at. If they see a JAIR article during an academic career review, it appears as a bone fide p-journal publication, and can be assessed on the basis of its content" (Kling and Covi). /pp. 12-13/ 
This approach raises the absolutely crucial point that print and electronic forms are already intimately related insofar as "every" p-publication prepared on a computer is always already an electronic text, that is, a virtual article. Of course, this realization tends to demystify print as the "origin" of ideas, knowledge and cultural memory. In practical terms, the distinction between document format and document delivery suggests that webpages, unlike their paper counterparts, do not necessarily have to actualize the content of virtual documents. In short, the Internet may best serve certain academic communities as a distribution system for virtual articles.

This advantage aside, I find that the polymorphous approach of the JAIR smacks of an ideological dodge by an ingenious double-agent who, at the end of the day, could find that s/he has merely earned the mistrust of both p-publishers and e-publishers. In other words, notwithstanding its positive points, this approach may have more points in common with a deceptive marketing strategy than it does with a workable strategy capable of addressing the problem, that is, the ideological problematic called papyrocentrism. Instead, papyrocentrism is accepted, encouraged and perpetuated by a strategy which purports to challenge it.

Elsewhere, the case made by Jean-Claude Guédon envisages an incremental transition to scholarly e-publishing which, again, is a partial solution. However, in this case, it constitutes only a partial solution, not because of its ideological weakness, but rather because it provides a temporary and intermediary solution: a tourniquet, but not a cure. In short, this approach offers incrementalism without deception. By temporarily incorporating the same characteristics of p-journals, e-journals will be able to aspire to the same legitimacy and, by extension, enter into competition with p-publications:

S'insérer dans le système de la recherche, c'est trouver le moyen de doter les publications électroniques des mêmes caractéristiques que les revues savantes imprimées de façon à pouvoir prétendre à la même légitimité et entrer ainsi dans le jeu de la concurrence entre revues. Pour atteindre /pp. 13-14/ 
cet objectif, il faut apprendre à faire temporairement de l'ancien dans le nouveau de façon à faire accepter le nouveau dans l'ancien. (Guédon, author's emphasis)

Of course, Guédon admits that such a move does not produce guaranteed results since identifying which elements of the 'old' should be incorporated into the 'new' is already risky business: "Ne pas mettre assez d'ancien, c'est mettre en péril le démarrage même d'une revue électronique savante; en mettre trop peut constituer un handicap à son déploiement éventuel selon le potentiel propre au nouveau médium" (Guédon).

There are essentially two important distinctions between the hard break subversive approach of Harnad and the incrementalist approach of Kling, Guédon and others. First of all, each approach manifests a certain attitude towards social change and how it comes about. Second, the "hard break" approach emphasizes the newness and difference of e-publishing while the incrementalist approach uses similarity between competing modes of publication to introduce, but to ultimately downplay (or at least defer) difference.

Harnad's approach is not very realistic in that people generally do not modify their beliefs until they are forced to do so. One should bear in mind that "good reasons" are rarely good enough to dislodge or destabilize beliefs that have always stood their believers in good stead. 8 By what stretch of the /pp. 14-15/

8 See also Ron Kling and Lisa Covi, "Electronic Journals and Legitimate Media in the Systems of Scholarly Communication," The Information So c ie ty 11.4 (1995): $\mathrm{N}$ ov 29, 1998

<http://www.slis.indiana.edu/TIS/klingej2.html>. "Harnad's proposal to move scholars from one set of communication systems to another has much in common with many utopian proposals: there is no effective analysis of how to encourage diverse scholars make a workable transition. In practice, scholars will become interested in e-journals at varying rates. Today, a scholar who is facing a choice between publishing in a p-journal and publishing in an e-journal (other than JAIR) faces a choice between legitimate (but perhaps slow) publication, and more rapid publication in e-journals that are viewed as of lesser quality (or even not serious journals). The e-journal may promise world-wide accessibility. But the scholar who wants to be read by his or her colleagues is more concerned that the article 
imagination would the scholars who control the A-list journals in their field feel obliged to start anew in the world of e-publications? Since Harnad does not suggest the use of force, one must assume that the force of his attack on traditional p-publishing lies in the value — rightness, usefulness, appropriateness - of e-publishing. In the last analysis, the claim is quite untenable because it does not target the strong beliefs about p-publications which determine the behaviour and attitudes of those who leverage the most power in the academy. Whereas cultural, racial and linguistic difference make legitimate claims to "protected status," e-publication has yet to invent such a claim.

Incrementalist approaches are founded upon a better understanding of how change works and how minds are changed 9 . Major changes imply major work, and believers do not change their minds when the work involved does not bring about significantly improved coherence among consciously held beliefs. Small changes, so the axiom goes, imply less work and, as a result, have better odds of succeeding. It is easier to make people believe that certain aspects of journals and books are more useful and functional in an electronic environment than it would be to make people believe that p-publications should be eliminated and replaced with e-publications. This may be especially true in the case of scholarly publication since, for academics, this constitutes or at least approaches the equivalent of what Charles S. Peirce once referred to as the "beliefs we learn on our mother's knee." These beliefs, he argues, cannot be changed; they are non-negotiable (Peirce).

/pp. 15-16/

be seen by valued peers than that it be seen by a possibly larger but much less influential group of readers. Today, p-journals are better able to promise appropriate readership than are e-journals, with a few exceptions."

9 See Gilbert Harman, Change in View: Principles of Reasoning (Cambridge, Mass.: The MIT Press, 1986). 
However, this said, it is true that stressing the similarity between p-publications and e-publications has had some negative effects. For example, considerable energy has been dedicated to formatting online documents to resemble $\mathrm{p}$-journal pages when the energy could have been more gainfully applied to resolving more pressing questions such as: How will scholars locate and search electronic texts? A wider implementation of multimedia objects in e-publication may also have been hindered by incrementalist approaches 10. And finally, the incrementalist approach may also prove too incremental, that is, too slow, for those of us who are used to the speed of modern communication systems.

\section{3) Metaphor as Strategy}

By retaining the concept of publication to describe "high-quality textual content" in the new electronic environments, the scholarly community has implicitly already rejected a hard break approach on the conceptual, or better, on the metaphorical level. In other words, our task is to legitimate the metaphor: WEBPAGES ARE PUBLICATIONS. Of course, this is not at all a unique or unusual approach, but quite a normal and natural linguistic "strategy." As Lakoff and Johnson have argued convincingly in Metaphors We Live By, metaphors and the coherence among metaphors constitute the very grounding of our "human reality." By allowing us to understand one kind of experience in terms of another - usually an abstract concept in terms of a more physical concept - metaphors make sense of our world and, indeed, make it what it is:

Each culture must provide a more or less successful way of dealing with its environment, both adapting to it and changing it. Moreover, each culture must define a social reality within which people have roles that make sense to them and in terms of which they can function /pp. 16-17/ socially. Not

10 See Ann Okerson, "Recent Trends in Scholarly Electronic Publishing," June 12, 1997, Yale University, Nov. 29, 1998 <http://www.library.yale.edu/ okerson/recent-trends.html>. 
surprisingly, the social reality defined by culture affects its conception of physical reality. What is real for an individual as a member of a culture is a product both of his social reality and of the way in which that shapes his experience of the physical world. Since much of our social reality is understood in metaphorical terms, and since our conception of the physical world is partly metaphorical, metaphor plays a very significant role in determining what is real for us. (Lakoff \& Johnson 146)

Clearly, there is nothing arbitrary, relativistic or decorative about the determination of metaphors: it is a matter of power and social control. That the literal concept of publication has been associated with publication on paper by a professional printing press since the middle of the 15 th century is not at all a chance or random event. Rather, it is a case of the expression of specific social, political and economic investments, in all senses of the term, in Gutenberg's invention.

Yet even before metaphors can become accepted concepts or beliefs, they must dethrone other metaphors. In short, they must be deployed as successful speech acts, if only to eventually be cast as obvious and "real." To phrase it somewhat differently, the metaphor WEBPAGES ARE PUBLICATIONS is a specific instance of a jeu de langage which can potentially legitimize e-publications on the WWW11. However, in 1999, I can state without reservations that this game is far from won. There is hardly any danger of dethroning, deforming or reforming the literal sense of publication (i.e. p-publication) in the near future. But this does not mean that there are not perhaps other strategies, that is, other jeux de langage capable of legitimizing scholarly and scientific e-publication. A s Jean-François Lyotard reminds us: "tout énoncé doit être considéré comme un 'coup' fait dans un jeu" (Lyotard, Condition 23).

/pp. 17-18/

11 See Jean-François Lyotard, La Condition postmoderne (Paris: Minuit, 1979); and Le Différend (Paris: Minuit, 1982). 


\section{4) Defining Publication in the Electronic Age}

One of the principal difficulties associated with extending the concept of publication to include Internet-based e-publication is that the term publication is already being used by a watershed of new media which all proclaim themselves publications or publishing media. This Babel of new terminology has raised considerable doubts as to which formal characteristics make a document a publication and which media are in fact publishing media. For example, consider the distinctions proposed in 1994-95 by the designers of the Electronic Publications Pilot Projet (EPPP) of the National Library of Canada:

For EPPP purposes, an electronic publication is a document resulting from formal publishing activities in which the information is encoded, accessed, and made intelligible by using a computer. This definition includes:

documents distributed in multiple copies on physical media, such as compact disks, CD-ROMs, diskettes and magnetic tapes; and

documents that reside on host computers and are accessible over a communications network.

Since the NLC is already acquiring and processing electronic publications on physical media, only the second category of electronic publications (networked or on-line publications) was studied. The project excluded certain types of documents available on the Internet, including electronic mail, Web documents that did not have the characteristics of traditional publications, some Gopher sites, on-line databases, file transfer protocol archives, and bulletin board systems. ("Electronic Publications Pilot Project")

My point is that "electronic publication" remains a fairly soft concept. As a result, it is easy to understand why scholars, whose reputation and power depends on their publications /pp. 18-19/ list12,

12 See Timothy Unwin, "Publish and/or Perish? On writing, scholarship and survival for the modern academic" Mots Pluriels 5 (1998): Nov. 29, 1998 <http://www.arts.uwa.edu.au/MotsPluriels/MP598tu.html>. "On the other 
are concerned by the mass and chaotic appropriation of the concept of publication by new e-media and e-genres.

Of course, it is only quite recently, after all, that the concept of publishing was extended to include desktop publishing. Nonetheless, desktop publishing has not been viewed as a formidable challenge to the sovereignty of p-publication since the thrust of the change affects the prepress process only and does not therefore imply changes in the nature or use of the support, that is, paper; nor does it necessarily affect how publications are marketed and distributed; or even how "gatekeepers" carry out their quality-control measures. This is why, in the case of the JAIR discussed earlier, scholars did not react negatively to the distribution of peer-reviewed articles in Postscript format. In short, as a form of electronic typesetting, desktop publishing implies a/pp. 19-20/

hand, publication nourishes - and is perhaps nourished by - that spectacular modern invention, the curriculum vitae. The art of the successful curriculum vitae in academe is intimately bound up with the art of achieving a lengthy list of publications, so much so that it has now become common practice to list absolutely everything one has ever published, right down to the shortest and most trivial book review. Such indeed is the pressure to publish, that bogus references to published material, or elastic use of the terms 'in press' and 'forthcoming', have become all too frequent on academic job applications. Alternatively, vertiginous lists of entirely genuine publications may often conceal tricks and sleight of hand in their presentation. There must be a dozen ways of legitimately listing an item twice in a curriculum vitae, and there is as well the now standard practice of double publication (where a piece is published first as an article, then as a chapter in a book). It could be interesting to do an in-depth study of the 'mythology' of the curriculum vitae, in Barthesian mode, with its implicit cult of the individual and its sub-text equating productivity (the absolute value) with quality. Such a study could concentrate on the technique of listing, which gives a veneer of credibility to even the most minor texts or activities (often equating unpublished conference papers or private reports with genuine printed material, for example), and it might look at the historical and social causes for the incredible rise of the curriculum vitae as a genre." 
redistribution of labour, but does not disrupt or revolutionize the social aspects of the publishing process. Desktop publishing does not alter our Western typographic "rules of the game". In fact, desktop publishing would be more accurately described as desktop prepress.

Since the mid-nineties, there has been an exponential increase in the use of publication metaphors. For example, today's wordprocessors often include programs called "Internet publishers" or include file commands such as "Publish HTML, SGML" and others. These new publication metaphors have in large part replaced the notion of "file formats" and "file handling operations" (ex. reformatting, save as, etc.). Of course, only certain file formats such as the HTML and SGML presentation mark-up languages are deemed worthy of the term publication. Now, as with desktop prepress, the very formatting (cf. format) of documents is considered publication. 13

Likewise, the CD-ROM is also "published" by so-called "CD-ROM publishers." The struggle for control of the publication metaphor is ongoing not only between print and electronic media, but also between competing electronic, or digital technologies. In an article entitled "The Changing Face of CD-ROMs," published in Publish magazine in February 1998, the author writes:

Putting CD-ROMs in a publishing context is a bit tricky. "The death of the CD-ROM has been greatly exaggerated" might be a start, but it wouldn't be quite right: the popularity of CD-ROM as a publishing medium is, in fact, eroding rapidly. Only a couple of years ago, CD-ROM books, magazines, and catalogs were promising projects, offering designers and publishers a means to integrate/pp. 20-21/

13 Similarly, related terms such as document no longer only refer to print documents. Whereas a few years ago the term file was predominant when referring to wordprocessing content, today the term document has largely replaced it. Furthermore, the term document refers not only to text-based content, but also to sound, image and video content. 
reflective editorial content with the latest interactive technologies. But although the Internet has eclipsed the CD-ROM as the preferred platform for interactive publishing, CD-ROM is still a practical medium for certain publishing projects. (Greenberg 67, my emphasis)

The author typically does not offer any explanation as to why CD-ROMs should be considered publications, but rather simply states their relevance to publishing, and this, not once, but five times in this brief passage. Implicitly nonetheless, the argument one can deduce is that a medium that can be used to make public and disseminate the content of "books, magazines, and catalogs" is, all other questions of specificity and process aside, a publication medium. Not surprisingly, a large part, if not most CD-ROM publishing, is undertaken by the multimedia departments of large publishing houses.

Even while public attention has been closely focused on Internet hypermedia and multimedia technology in recent years, the concepts of printing and publishing have also been the subject of rapid technological change in the printing industry (cf. publishing industry). As Frank Romano, the founder of Electronic Publishing magazine, writes:

Winston Churchill once said that the United States and Great Britain were two great nations divided by a common language. Sometimes the printing and publishing industries seem to be in the same predicament. Suppliers use terminology to their own end and users are not always savvy enough to challenge them. Also, technology is changing so fast that terminology is often a blur as it tries to keep up with rampant change. (Romano 14)

Romano goes on to define a series of closely interrelated terms, including digital printing, direct imaging, variable printing, on-demand printing, distributed printing, digital press and workflow and, last but not least, print. He reminds us that "[1]ike /pp.21-22/ all 
terms, we can make print mean what we want" (Romano 14). Here is the Nietzschean seduction, the "will to power" expressed in the determination of the meaning and value of the term print. Romano continues: "So let us all make it mean the communication of information via spots on paper, data on disks, or pixels on video screens, produced with digital technology" (Romano 14). This sentence seems less a definition than it is an exhortation of a minor prophet of the print world urging us through the difference-levelling logic of the metaphor, PRINT IS COMMUNICATION OF INFORMATION, to radically redefine print and publication to include all of the members of the new "digital family."

Compare this assertive strategy to the negative rhetoric of the integration strategies of the past that introduced us to the wireless, the cordless telephone and the horseless carriage. Strangely, perhaps, the term paperless publication has not really been used with respect to electronic publication. Rather, it has a narrower usage, most often used to express practical concerns about the waste and cost of paper. Manufacturers of scanners, for example, have been quick to employ terms like the paperless office or the paperless cubicle14. If paperless is not associated with electronic publication, it is likely due to the fact that it is bound up with the idea of storing private papers for personal, or at least non-public use.

And so while the World Wide Web may be the most popular, accessible, universal and affordable means of electronic publication, as we have seen, it is manifestly not alone in its claim to publication status. The surplus of expressions used to refer to web publication speaks to its mass appeal: electronic publication, online publication, network publication, Internet publication, digital publication, virtual publication, web publication. Not all web pages are publications in the narrow sense favoured by scholars and scientists. Yet for web insiders, and especially for "wired academics," it is clear which sites constitute publications in the narrow sense, as defined as analagons or extensions of /pp. 22-23/ scholarly

14 For example, see Stanford Diehl, "The Paperless Cubicle," BYTE Magazine $\quad \mathrm{M}$ arch $1996, \mathrm{~N}$ ov.29, 1998 <www.byte.com/art/9603/sec11/art7.htm>. 
publications on paper. However, for many people, the differences between web genres are far from obvious. "What seemed fairly simple in the world of print (for example, knowing the difference between a publication and a private letter) begins to be more complicated in a medium where formal discourse and chit-chat flow in the same pipeline" (Okerson \& O’Donnell, Ch. 12).

Web genres are nonetheless slowly taking form; web readers are becoming more sophisticated. For example, homepages, which are perhaps the oldest and most well-known web genre, do not usually invoke the publication metaphor. Rather, one often hears: "I have a homepage"; "I put up a homepage," but very rarely "I publish a homepage." The leading metaphor of the web is spatial: the website. "What is the address of your site?" "What is CBC Newsworld's address?" Still, the public, including scholars, is slowly coming to differentiate among "net graffiti," formal e-publications, and the tumultuous and voluminous "everything in between." In the next few years, I predict that web genres will develop to the point where fears about confusing a scholarly e-publication with "network chatter" will seem almost as absurd as the reaction of Orsen Welles' listeners who mistook a simple radio presentation of War of the Worlds for a Martian invasion.

\section{5) Beyond the Publication Principle}

The use of the term publication to describe the many new supports of the hypermedia, multimedia and printing industries is an essentially efficient use of a metaphorical strategy. Yet at best, these publication metaphors only tell half the story, because metaphors invariably emphasize similarities over differences in the conceptual fields compared. Differences, as Lakoff and Johnson demonstrate in Metaphors We Live By, are not so much absent as they are overshadowed, or overpowered by similarities:

The very systematicity that allows us to comprehend one aspect of a concept in terms of another (e.g. comprehending an aspect of arguing in terms of battle) will necessarily hide other aspects /pp. 23-24/ 
of the concept. In allowing us to focus on one aspect of a concept (e.g. the battling aspects of arguing), a metaphorical concept can keep us from focusing on other aspects of the concept that are inconsistent with that metaphor. (Lakoff and Johnson 10)

Defining publication in the electronic age has, thus far, been an exercise in repression, denial or, at the very least, deferral. And whereas the term publication and its cognates may be overused, the specificity of new publication technologies has remained sadly under-represented.

What has been denied or deferred in metaphors of electronic publication today is, for me, exactly what urgently needs to be communicated and legitimized or, in a word, protected. Instead of attempting to smuggle in the new in the Trojan guise of the old, a metaphor - a language game (jeu de langage) - is needed that would allow the specific advantages of the electronic medium to be highlighted, appreciated and developed. The approach that I am proposing is neither technological or design-oriented, nor does it require the suspension of disbelief, as with Harnad's subversive proposal. My proposal is discursive and therefore political and ideological: we need to rethink and re-represent electronic publishing conceptually and, by extension, metaphorically. This will be a considerable undertaking, but I would at least like to set the stage for further research, discussion and experimentation along these lines.

Consider, by way of analogy, the emergence and legitimization of artistic photography in nineteenth-century France. Artists were originally denied the right to express themselves through the photographic medium since the "soulless machine" was seen as severely limited: the camera could only produce exact copies of the physical world, not interpretations or representations. How could photographers claim rights to the "real"? Soon, however, the notion of technique emerged. Technique implies personality, and personality and reputation are protected in French civil law. "Photography appears a second time. The 'Soulless machine' becomes the vehicle of the 'Soul of Man' whose essence /pp. 24-25/ is private property" (Tagg 113). But what, correlatively, will be the 
protected value of scientific and scholarly e-publication? My proposal is hardly subversive. In fact, it is a metaphor that darts in and out of many formal statements on the subject of online publication: SCHOLARLY PUBLISHING WEBSITES ARE COMMUNITIES. Despite the fact that webpages are merely copies requested manually, by clicking on a mouse, they are conceived in spatial terms. Community is a logical metaphor for this space since it represents space that is always already socialized and codified: communities are legitimate social formations. In today's society, most communities possess a de facto right to protected status, unlike the complex and arguably underdefined concept of electronic scholarly publication. 15

With respect to the technology required, creating online scholarly communities could be simply a matter of emphasizing the relation between electronic publications and their community-based online environments, such as online discussion boards and listservs, conference announcements, site archives and feedback pages. Of course, many electronic scholarly publications have already integrated such features, even though they have not chosen to emphasize the community metaphor. The oldest scholarly electronic publication, Postmodern Culture (1990- )16, offers a /pp. 25-26/

15 In a recent search of Altavista (Nov. 29, 1998 $<$ http://altavista.digital.com>) for documents in English (only), "community" was by far the most frequently occurring word among other leading "values" in today's society: "publication" $(4,664,640)$, "money" $(7,609,768)$, "sex" $(8,739,716)$, "community" (17,328,655).

16 See Postmodern Culture, eds. Lisa Brawley and Stuart Moulthrop, 3 Aug. 1998, Johns Hopkins University Press, Nov. 29, 1998 <http://www.iath.virginia.edu/pmc> ; "Sites of Significance for Semiotics," Applied Semiotics/ Sémiotique appliquée, eds. Pascal Michelucci and Peter Martienson, May 1997, Department of French, University of Toronto, Nov. 29, $1998<$ http://www.chass.utoronto.ca/french/as-sa/EngSem1.html> ; Early Modern English Studies, Ed. Raymond Siemens, 1998, University of Alberta, Nov. 29, 1998 <http://purl.oclc.org/emls/emlshome.html> ; Humanist Discussion Group, ed. Willard McCarty, Centre for Computing in the Humanities, King's College London, Nov. 29, 1998 $\langle$ http://www.princeton.edu/ mccarty/humanist $>$. 
listserv, a feedback page and even a feedback archive. Applied Semiotics/Sémiotique appliquée (AS/SA) offers a very practical and well-presented resource page called "Sites of Significance for Semiotics." Attracting users is the first step to establishing the community qua readership which make scholarly e-publications the dynamic media that they are. Early Modern English Studies (EMLS) offers a listserv, but also invites readers to participate in the Humanist Discussion Group, a very important and useful list for humanists. It is interesting to note that none of these exemplary publications identifies itself, that is, metaphorizes itself as an online community in its introductory remarks. Certainly, they fulfill the role of community significantly better than the paper "write journal"17 does or ever did. Yet Postmodern Culture does not include any prefacial remarks at all; $A S / S A$ introduces itself as an "academic journal" and as a "revue de recherche"; and EMLS presents itself as a "formal arena for scholarly discussion and as an academic resource for researchers in the area." The use of traditional metaphors represents, as I see it, missed opportunities to help establish the protected status of scholarly e-publications as online scholarly communities.

An electronic publication is not merely a paper publication in disguise or an upbeat vanity press. Scholarly e-publications are specialized virtual communities, places to engage in discussions, to test ideas and to publish texts (cf. papers). They are safe places, dynamic places, good places. Reconceiving scholarly electronic publications in this way would, in my view, be an important step in moving beyond the publication principle.

\section{Rod Heimpel Department of French University of Toronto}

Presented in a slightly altered form on 28 May 1998 at the HSSFC Congress for ACCUTE and the Consortium for Computing in the Humanities, University of Ottawa.

17 See Rob Kling and Lisa Covi. The authors use this term to describe journals in which scholars publish, but to which they seldom return (except to reread their own material). They represent the anti-thesis of the community-based model adopted - but not promoted per se — by scholarly e-publications. 


\section{References}

Applied Semiotics/ Sémiotique appliquée. Eds. Pascal Michelucci and Peter Martienson. 4 Nov. 1998. Department of French, University of Toronto.

$<$ http://www.chass.utoronto.ca/french/as-sa/> .

Austin, John L. How to do Things with Words. Oxford: Oxford University Press, 1962.

Bailey, Charles W., Jr. "Network-Based Electronic Publishing of Scholarly Works: A Selective Bibliography." The Public-Access Computer Systems Review 6.1 (1995): 5-21.

"The Changing World of Scholarly Communication: Challenges and Choices for Canada. Final report of the AUCC-CARL/ABRC Task Force on Academic Libraries and Scholarly Communication." Nov. 1996. Association of Universities and Colleges of Canada and the Canadian Association of Research Libraries. <http://homer.aucc.ca/english/sites/aucccarl.htm>.

DesJardins, Joseph. "Status of ETD Initiatives in the US and Canada." Sept. 1997. Joint Electronic Thesis and Dissertation Project of the Faculty of Information Studies at the University of Toronto, University of Toronto Libraries and York University Libraries. $<$ http://www.fis.utoronto.ca/etd/report1.htm>.

Diehl, Stanford."The Paperless Cubicle." BYTE Magazine March 1996. <www.byte.com/art/9603/sec11/art7.htm>.

Early Modern English Studies. Ed. Raymond Siemens. University of Alberta.<http://purl.oclc.org/emls/emlshome.html>.

/pp. 27-28/ 
"The Electronic Library and the Future of Scholarly Communication," a.c.u. bulletin of current documentation (Association of Commonwealth Universities) 131 (1997): 10-16.

"Electronic Publications Pilot Project (EPPP)- Final Report." March 26, 1997. National Library of Canada. <http://collection.nlc-bnc.ca/e-coll-e/edown.htm>.

Greenberg, Ilan. "The Changing Face of CD-ROM's." Publish (February 1998): 67-71.

Guédon, Jean-Claude. "L'édition savante et l'autoroute électronique." March 8, 1994. Centre de recherche en droit public.

$<$ http://www.droit.umontreal.ca/crdp/fr/equipes/technologie/

conferences/ae/guedon.html> .

Harman, Gilbert. Change in View: Principles of Reasoning. Cambridge, Mass.: The MIT Press, 1986.

Humanist Discussion Group. Ed. Willard McCarty. Centre for Computing in the Humanities. King's College London. $<\mathrm{http}: / / \mathrm{www}$.princeton.edu/ mccarty/humanist>.

Journal of Artificial Intelligence Research. Ed. Michael Wellman. 1998. AI Access Foundation, Inc. <http://www.jair.org/>.

Kling, Ron and Lisa Covi. "Electronic Journals and Legitimate Media in the Systems of Scholarly Communication." The Information Society 11.4 (1995). <http://www.slis.indiana.edu/TIS/klingej2.html>.

Lakoff, George and Mark Johnson. Metaphors We Live By. Chicago: University of Chicago Press, 1980.

Lyotard, Jean-François. La Condition postmoderne. Paris: Minuit, 1979.

. Le Différend. Paris: Minuit, 1982.

"New Jour: Electronic Journals and Newsletters." Eds. Ann Shumelda Okerson and James J. O’Donnell. Nov. 29, 1998. University of California at San Diego Libraries. <http://gort.ucsd.edu/newjour/>. 
Okerson, Ann. "Back to Academia: The Case for American Universites to Publish Their Own Research." Yale University. <http://www.library.yale.edu/ okerson/case.html>. Originally published in Logos 2.2 (1991): 106-112. . "Recent Trends in Scholarly Electronic Publishing." June 12, 1997. Yale University. <http://www.library.yale.edu/ okerson/recent-trends.html>.

Peirce, Charles Saunders. "The Fixation of Belief." Philosophical Writings of Peirce, Justus Buchler, ed. New York: Dover Publications, 1955. 5-22.

Postmodern Culture. Eds. Lisa Brawley and Stuart Moulthrop. 3 Aug. 1998. Johns Hopkins University Press. <http://www.iath.virginia.edu/pmc>.

Romano, Frank. "Digital definitions." Electronic Publishing (January 1998): 14.

"Scholarly Journals at the Crossroads: A Subversive Proposal for Electronic Publishing: An Internet Discussion about Scientific and Scholarly Journals and Their Future." Eds. Ann Shumelda Okerson and James J. O’Donnell. April 9, 1998. Association of Research Libraries, Washington, DC. <http://www.arl.org/scomm/subversive/sub01.html>.

Tagg, John. The Burden of Representation. Amherst: The University of Massachusetts Press, 1988.

Unwin, Timothy. "Publish and/or Perish? On writing, scholarship and survival for the modern academic" Mots Pluriels 5 (1998).

<http://www.arts.uwa.edu.au/MotsPluriels/MP598tu.html>.

/p. 29/ 